\title{
AFFECTIVE POSITIONING IN MACEDONIAN INTERNET FORUM DISCUSSIONS
}

\author{
Fevzudina Saračević \\ AUE-FON University, Skopje \\ fevzudina@gmail.com \\ Liljana Mitkovska \\ AUE-FON University, Skopje \\ liljana55@yahoo.com
}

The broader interest of this study is Macedonian internet discourse, particularly how people on the Internet adopt stance towards what they state and towards their interlocutors. The focus here is on affective stance, or the emotional reactions of participants, in two internet forum discussions on the COVID-19 pandemic. Interactional sequences related to alternative explanations, so called conspiracy theories (CTs), have been extracted and manually annotated employing a descriptive framework of evaluative language based on the tenets of systemic functional linguistics. We distinguish four main semantic categories of $A F F E C T$, considering three factors: polarity, orientation and expression. Our interest is mainly in the similarities and differences of affective positioning as expressed by three groups of participants, based on their orientation towards the CTs discussed: supporters, opponents and uncertain. The results show that negative $A F-$ FECT prevails, usually as a combination of Insecurity, Unhappiness and Dissatisfaction, triggered by external factors and entities, and most often expressed with a verbal phrase. Expressions of AFFECT appear to serve not only to voice feelings but also to aid stancetaking more generally.

Keywords: Internet discourse, stancetaking, AFFECT, COVID-19 


\title{
ИЗРАЗУВАЫЕ ЧУВСТВА ВО ДИСКУСИИТЕ НА МАКЕДОНСКИТЕ ИНТЕРНЕТ-ФОРУМИ
}

\author{
Февзудина Сарачевиќ \\ АУЕ-ФОН Универзитет, Скопје \\ fevzudina@gmail.com \\ Лилјана Митковска \\ АУЕ-ФОН Универзитет, Скопје \\ liljana55@yahoo.com
}

Во ова истражување се испитува македонскиот интернет-дискурс, особено тоа како луѓето заземаат став кон она што го кажуваат и кон своите соговорници при комуникацијата преку интернет. Во оваа статија фокусот е на емоционалниот став, односно на емоционалните реакции на учесниците во две форумски дискусии што се однесуваат на пандемијата на КОВИД-19. Од овие дискусии се извадени секвенции со интеракција во врска со алтернативни објаснувања, т.н. теории на заговор (Т3) и се мануелно анотирани со употреба на дескриптивна рамка за евалуативен јазик заснована на приниципите на системската функционална лингвистика. Разликуваме четири главни семантички категории на АФЕкт, кои ги разгледуваме во поглед на три фактори: поларитет, ориентација и експресија. Нашиот интерес се, главно, сличностите и разликите при афективното позиционирање во поглед на три групи учесници, поделени според нивниот став кон Т3 што се дискутираат: поддржувачи, противници и неодредени. Резултатите покажуваат дека

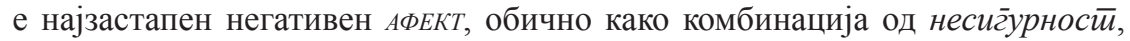

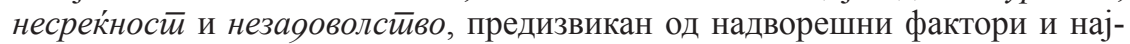
често изразен преку глаголска фраза. Искажувањето АФЕкт се покажа дека служи не само да се изразат чувствата туку и да се поткрепи заземањето став воопшто.

Клучни зборови: интернет-дискурс, заземање став, АФЕКт, КОВИД-19 


\section{Introduction - CMC and internet forum discussions}

Discussions on internet fora have become an increasingly popular type of communication among internet users, especially during the past two years with the COVID-19 pandemic. Language and discourse in these discussions is particularly interesting in linguistic terms since it represents a genre of its own, incorporating features of both spoken and written language, but also some characteristics peculiar to the forum as a medium. The term Computer Mediated Communication, or CMC, (Herring 1992) was one of the first to encompass various approaches to studying language and communication on the internet. In recent years, however, as new ways of digital communication develop, different approaches need to be applied in order to deal with the emerging discourses. Our study falls closest to what has recently been termed 'digital discourses', lying 'at the intersection of (non)language resources, society and technology.' (Bou-Franch and Garcès-Conejos Blitvich 2018: 4)

Our research data is a part of the discourse on internet forum discussions. Specifically, we focus on two popular Macedonian internet fora, forum.femina.mk and forum.kajgana.com. We are particularly interested in interaction sequences in which the so called conspiracy theories (CTs) are debated. CTs are seen here as alternative explanations to official factual information about the origin of the virus, the purpose of its release, the involvement of various social actors in the virus spread, as well as to a number of COVID-19 related topics discussed on the fora. While internet discussions have been researched more extensively in languages such as English (Arendholz 2013), Greek (Angouri and Tseliga 2010), German (Ehrhardt 2014), and Chinese (Shum and Lee 2013), there have been hardly any attempts to study them in Macedonian context (see recent studies of Mitkovska and Saračević 2021; and Saračević 2021). Our aim with this research is therefore to contribute to the study of digital discourses in Macedonian more generally, but more specifically it is to identify defining features of expressing affective stance in Macedonian internet forum discussions on the COVID-19 pandemic. One of the contributions of this study is also the application of the Appraisal Framework, which is based on English, to other languages, in this case Macedonian.

We analyse the affective positioning of participants in selected discussion threads, focusing on the polarity, orientation and expression of emotional states and reactions. We are particularly interested in the type of AFFECT discussants express, what triggers it and towards whom it is oriented, as well as in the array of linguistic expressions employed, ranging from explicit adjectival phrases to implicit discourse-level attitudinal positioning. Eventually, we want to establish how affective positioning contributes to the overall stancetaking of participants towards the topics discussed and towards one another.

Through quantitative and qualitative analysis of the selected interactional sequences, the article draws attention to dominant patterns of positioning of participants in argumentative discussions on COVID-19 related CTs. The paper is organised as follows: section 2 introduces the theoretical basis for the analytical 
framework, and section 3 outlines the data collection and research methods. Section 4 presents the results, while section 5 is devoted to further discussion of the findings. Finally, section 6 provides the concluding remarks.

\section{Theoretical background - affective positioning}

The notion of $A F F E C T$ has been used extremely variably, and emotions have been researched from a number of theoretical approaches, from those influenced by traditional psychological classifications to the recently popular sentiment analysis. In this study we follow a functional semiotic approach set at the discourse-semantic level, as defined by Martin and White (2005) in their descriptive framework of evaluative language, called the Appraisal Framework. Appraisal is concerned with text, or meaning beyond the clause, for three reasons (ibid, 10): (1) attitude can be realised across a phase of discourse, irrespective of grammatical boundaries - especially where amplified; (2) it can be realised across a range of grammatical categories; and (3) attitude meanings can be realised with different wordings. This framework is based on Hallidayan systemic functional perspective of language. It is concerned with the interpersonal metafunciton of language: the interaction with the social world by negotiating social roles and attitudes, thus enacting social relations (Halliday 1978).

Martin and White (2005) define $A F F E C T$ as "evaluation by means of the writer or speaker indicating how they are emotionally disposed to the person, thing, happening, or state of affairs" (ibid, 42). In their framework, AFFECT is the critical domain, one of the components of ATTITUDE, and as we argue below, AFFECT plays an important role in the overall expression of stance. It is seen as very explicitly subjective, having the effect of strongly personalizing the text, or foregrounding the individual role of the author and their evaluative position in producing and shaping the text. It can be represented through authorial (1st person) or non-authorial (2nd or 3rd person) emotional reactions (Martin 2000). Thus there is a need to identify the appraiser (emoter/evaluator), or the person who is feeling something (emoting), and the appraised (trigger/evaluated), the person, thing or activity that is being reacted to.

Emotions under the AF are classified as systems of oppositions, based on the following six factors: polarity, gradability, internalisation, orientation, intention, and semantics (Martin and White 2005: 49-52). In our study we start from the semantic categorisation, which proposes four main groups of feelings, each with a positive and a negative side: (un)happiness, (in)security, (dis)satisfaction and (dis) inclination (ibid). These feelings can be expressed in discourse either by explicitly affective lexical items, or only implied and understood from the overall tone of an utterance. They can take the form of a more prototypical adjectival phrase, or occupy a stretch of discourse.

Finally, the role of $A F F E C T$ in stancetaking needs to be considered. For this purpose, we follow studies which take a similar, social approach to studying $A F F E C T$ as part of stancetaking (e.g. Du Bois 2007; Barton and Lee 2013; Kiesling et al. 2018). Barton and Lee (2013) maintain that to take a stance means to take a position, to express a certain view in relation to what is said, to oneself, and to other people and 
objects (ibid, 87). Stance is seen as a complex multi-layered phenomenon involving many aspects, whereby AFFECT, i.e. emotional attitude, is accompanied by investment, i.e. epistemic attitude, and alignment, i.e. relational attitude. Additionally, stancetaking is highly dependent on surrounding co-text and context, in that "every utterance in interaction contributes to the enactment of stance, even if this stance is only evoked and not explicitly spelled out” (Du Bois and Kärkkäinen 2012: 438). Focusing on affective positioning, we follow Kiesling et al. (2018) who argue that $A F F E C T$ is not only found in evaluative lexemes, but also in the tone of an utterance. What these approaches have in common is the consensus that language is shaped by the relationships between the speaker/writer and the audience, the object of discussion, and the talk itself. In turn, language is used to reshape these relationships over the course of an interaction.

Based on the definition of affective positioning provided above and on our previous studies conducted on internet forum discourse in Macedonian, we expect that influenced by the socio-political conditions, the features of the forum and those of the discussion, and additionally provoked by responses of fellow participants, discussants will express mainly negative $A F F E C T$ triggered by and directed at subjects and issues pertaining to the current situation, with positive $A F F E C T$ largely underrepresented. Through $A F F E C T$ discussants are expected to not only express feelings but also to aid their overall stancetaking, amplifying their claims where needed, or lowering the costs when opposing.

\section{Data and method}

The data for this study consists of internet discourse retrieved from the two most popular Macedonian internet fora: Kajgana and Femina. These fora share features with other similar platforms in that they support asynchronous, semi-public, anonymous, many-to-many communication with messages of varied length that are permanent and predominantly textual. Both fora have a large number of members actively communicating on a wide range of topics. With the outbreak of the coronavirus epidemics general discussion threads on this topic were opened on both fora at the end of January 2020. ${ }^{1}$ Apart from information about the development of the pandemic situation, both locally and globally, and about new findings related to the virus and its effects, discussants also shared information about various CTs that had started to circulate on the internet.

For the purpose of this study, we created a corpus of sequences with debates on various conspiracy theories, a sample chosen from all posts contributed to the two threads from March 15 through May 15, 2020 on the Kajgana thread (about 8000 posts) and from January 26 till May 1, 2020 on the Femina thread (about 20000 posts). In the end, 109 sequences (66 from Kajgana and 43 from Femina) containing 621 posts (302 from Kajgana and 319 from Femina) were extracted for analysis and tagged for the below defined AFFECT categories. These particular timeframes were chosen because an initial view of the sites showed that posts before the

\footnotetext{
${ }^{1}$ They are entitled: "Coronavirus in Macedonia and the world" (Kajgana, January 26, 2020); "Coronavirus: the situation in Macedonia and the world" (Femina, January 24, 2020).
} 
specified date on Kajgana were less CT related and in May 2020, as the COVID-19 crisis continued, CT topics were moved to separate threads.

In the first phase of annotation, depending on the expressed views towards the CTs discussed, each participant was characterised as a supporter (total of 254 posts), an opponent (280 posts), or uncertain (indeterminate) (87 posts). Supporters advocated at least one CT, while opponents expressed objection to CTs shared in the thread or encountered elsewhere. As discussants usually shared more than one post, their orientation was read from all of the posts they contributed. Discussants represented with only one indeterminate post or several posts without taking a clear position to any CT were categorised as uncertain.

In the second phase, subcategories of $A F F E C T$ were defined based on semantics and polarity, which were then used as annotation tags. Each post was first annotated for explicit values, and then for implicit ones. To decide whether an utterance contains affective evaluation, we followed Martin and White's (2005) suggestion for a leading question: "Is there an evaluation of some human subject individual or group which is represented as making an emotional response or being in an emotional state? - or alternatively - Does it fit the collocational frame: person feels / AFFECT value/ about something; or it makes person feel /AFFECT value/ that [proposition]?" (ibid, 58). However, in answering these questions we had to consider not only lexis but also grammar, discourse markers, particles, punctuation, emoji, and additionally check our judgements against the preceding and following context. Our annotation scheme thus consisted of the following categories/tags, in which ' + ' stands for positive, and '-' stands for negative AFFECT:

EXP (explicit AFFECT)

IMP (implicit AFFECT)

HAP+ (happiness: cheer, affection)

HAP - (unhappiness: misery, antipathy)

$\mathrm{SEC}+$ (security: confidence, trust)

SEC- (insecurity: disquiet, distrust)

SAT + (satisfaction: interest, pleasure)

SAT- (dissatisfaction: ennui, displeasure)

INC+ (inclination: desire)

$\mathrm{INC}+$ (disinclination: non-desire)

As shown in Figure 1 below, the annotation was done in a spreadsheet, with eight columns for annotation.

\begin{tabular}{|c|c|c|c|c|c|c|c|c|c|}
\hline Participant & Post content & Group & $\begin{array}{l}\text { EXPLICIT } \\
\text { AFFECT }\end{array}$ & Appraising item & Appraiser & Appraised & Expression & $\begin{array}{l}\text { IMPLICIT } \\
\text { AFFECT }\end{array}$ & INP feeling \\
\hline 1. & CT sequence: The virus is purposefully released & & & & & & & & \\
\hline \#5 UserABC & $\begin{array}{c}\text { Уште една у низата намерно пуштени вируси, } \\
\text { бнотероризам на најјако. Се надевам ќе се смпри } \\
\text { пандемијата и кее нема многу човечки жртви... }\end{array}$ & supporter & INC+ & $\begin{array}{l}\text { се надевам } \\
\text { 'I hope' }\end{array}$ & the discussent & $\begin{array}{l}\text { the situation with } \\
\text { the pandemic }\end{array}$ & $\mathrm{VP}$ & SEC- & worry \\
\hline
\end{tabular}

Figure 1. Annotation example

In the above given example (Figure 1), explicit $A F F E C T$ is illustrated by ce наяевам 'I hope', and this verbal phrase (VP) is taken as a token of inclination, thus positive AFFECT. The appraiser is the participant themself and the appraised is the situation with the pandemic. Finally, the form $A F F E C T$ takes in this case is a VP (first person, present). For implicit $A F F E C T$ we only identified the category and the 
feeling expressed since it was not always possible to distinguish finer details. The implicit value of Insecurity in the sense of worry has to be read from the whole content of the post: no overt 'I am worried' is present, but the surrounding context, including 'bioterrorism at its best', 'many casualties' and the hope for the pandemic to come to a halt are all clues of worry on the part of the participant.

Finally, the percentages for each category were calculated against the number of tags, not the number of posts, because some posts were annotated for more than one AFFECT value. The quantitative data was attained through sorting on a spreadsheet and these will be presented below, followed by a discussion of the qualitative analysis.

\section{Results}

The results below are presented following the three factors we considered in our analysis: polarity (4.1), orientation (4.2), and expression (4.3). The analysis of stancetaking is included in the discussion in section 5.

\subsection{Semantics, explicitness and polarity}

Under polarity we considered whether the feelings we annotated are popularly construed by the culture as positive or negative ones. Thus we had a tripartite distinction: positive, negative, and neutral. Table 1 below shows that while $79 \%$ of all posts were marked for at least one value of $A F F E C T, 71 \%$ of them expressed negative AFFECT. This negativity is mostly evident in the group of supporters, with $80 \%$ of their posts expressing negative feelings. Similarly distributed polarity is present in posts of opponents. The highest number of neutral posts was found in the group of participants not taking a definite position to the topic discussed, the uncertain. They also had fewer negatively polarised contributions than the other two groups. This suggests that the more indeterminate a discussion participant is towards the discussion topic, the fewer (negative) emotions they will express in their posts (contributions).

Table 1. Polarity of AFFECT within the three groups of discussants

\begin{tabular}{lcccccccc} 
& \multicolumn{2}{c}{ Negative } & \multicolumn{2}{c}{ Positive } & \multicolumn{2}{c}{ Neutral } & \multicolumn{2}{c}{ Total } \\
Supporters & 351 & $80 \%$ & 28 & $6 \%$ & 60 & $14 \%$ & 439 & $100 \%$ \\
Opponents & 261 & $68 \%$ & 37 & $10 \%$ & 86 & $22 \%$ & 384 & $100 \%$ \\
Uncertain & 89 & $55 \%$ & 16 & $10 \%$ & 57 & $35 \%$ & 162 & $100 \%$ \\
Total & $\mathbf{7 0 1}$ & $\mathbf{7 1 \%}$ & $\mathbf{8 1}$ & $\mathbf{8 \%}$ & $\mathbf{2 0 3}$ & $\mathbf{2 1 \%}$ & $\mathbf{9 8 5}$ & $\mathbf{1 0 0 \%}$
\end{tabular}

When AFFECT values are looked at as divided in eight categories based on polarity and semantics, we get a clearer picture on what the above presented negativity consists of (Table 2). As can be seen, positive feelings are uncommon, present in only $10 \%$ of posts. It is noticeable that most present are feelings of Insecurity, Unhappiness and Dissatisfaction. We discuss them in more detail in section 5 below and we provide instances from the discussion threads. 
Table 2. Expression of AFFECT by categories

\begin{tabular}{|c|c|c|c|}
\hline Category & \multicolumn{2}{|c|}{ Tags/part } & Individual tags \\
\hline Happiness & 18 & $2 \%$ & admiration, gladness, compassion \\
\hline Unhappiness & 250 & $32 \%$ & $\begin{array}{l}\text { indignation, contempt, hatred, dislike, disgust, } \\
\text { sadness, misery }\end{array}$ \\
\hline Security & 6 & $1 \%$ & calmness, certainty \\
\hline Insecurity & 263 & $34 \%$ & $\begin{array}{l}\text { suspicion, concern, worry, anxiety, fear, } \\
\text { uncertainty, disbelief, tension, surprise }\end{array}$ \\
\hline Satisfaction & 5 & $1 \%$ & satisfaction \\
\hline Dissatisfaction & 141 & $18 \%$ & discontent, anger, frustration, disappointment \\
\hline Inclination & 47 & $6 \%$ & optimism, hope \\
\hline Disinclination & 50 & $6 \%$ & pessimism \\
\hline Total & 780 & $100 \%$ & \\
\hline
\end{tabular}

Feelings of Insecurity (found in 34\% of posts) are most common, with suspicion (expectedly) ranking highest (in $19 \%$ of posts), followed by concern (8\%), and worry (5\%). Suspicion was expressed towards most information coming from authorities and media, as well as towards personal experiences shared by discussants. Concern and worry appeared to be triggered by the rapid spread of the pandemic and the perceived unpreparedness of local and global authorities, and often regarding personal and family members' health. Insecurity is closely followed and often accompanied by feelings of Unhappiness (found in 32\% of posts), which range from indignation (in 14\% of posts), contempt (9\%) and hatred (3\%), to misery and sadness $(<3 \%)$. Indignation was mostly triggered by perceived improper behaviour of authorities and social actors as well as discussants themselves, while contempt and hatred covered more specific nations and groups, such as the Chinese or the WHO. Dissatisfaction is the third most present group of negative feelings (found in $18 \%$ of posts) expressed mainly as discontent, anger, frustration and disappointment. Dissatisfaction, too, was often triggered by behaviour of local and global actors during the crisis, and of participants in the discussion. In one-third of the posts, however, there is a combination of multiple feelings, which are discussed and exemplified in section 5 below.

\subsection{Orientation}

In distinguishing what is evaluated and what the trigger of affective positioning in the posts analysed is, we came up with two main categories: external and internal. Within these categories we made the distinction of whether reactions were provoked by or directed at internal subjects, i.e., other participants in the discussion as well as all forum users (including moderators and administrators), or at external subjects (social actors mentioned in relation to the pandemic situation), as well as issues and topics discussed. The results in Table 3 below are presented coupled with the previously illustrated division of $A F F E C T$ based on polarity (Table 1 above). 
It can be seen that $89 \%$ of the $A F F E C T$ in all posts is triggered by external subjects, whereby $79 \%$ of it is negative. Only $11 \%$ of the affective values are oriented at internal subjects, that is, participants in the discussion, with almost all of them being negative, mostly present in posts by the group of opponents, oriented at supporters.

Table 3. Polarity and orientation of AFFECT

\begin{tabular}{|c|c|c|c|c|c|c|c|}
\hline \multirow{2}{*}{$\begin{array}{l}\text { Polarity/ } \\
\text { Orientation }\end{array}$} & \multicolumn{3}{|c|}{ Negative } & \multicolumn{3}{|c|}{ Positive } & \multirow[b]{2}{*}{ Total } \\
\hline & ext & ernal & internal & ex & ernal & internal & \\
\hline Supporters & 317 & $84 \%$ & $349 \%$ & 27 & $7 \%$ & $0 \quad 0 \%$ & $378 \quad 48 \%$ \\
\hline Opponents & 212 & $71 \%$ & $49 \quad 16 \%$ & 35 & $12 \%$ & $21 \%$ & $298 \quad 38 \%$ \\
\hline Uncertain & 85 & $82 \%$ & $3 \%$ & 15 & $14 \%$ & $11 \%$ & $105 \quad 14 \%$ \\
\hline Total & 614 & $79 \%$ & $87 \quad 11 \%$ & 77 & $10 \%$ & $30 \%$ & $781 \quad 100 \%$ \\
\hline
\end{tabular}

The most common external triggers were found to be the local authorities (often the minister of health, doctors, and the government, as in examples 9 and 10 below), local people, humanity in general, some countries (mainly the USA, Russia and China), and some socio-political actors (often WHO, Bill Gates, renowned scientists, and organisation representatives, as in examples 6 and 8 below). There is also negative evaluation of (local) media (in 2, 6 and 10 below) represented as causing mainly feelings of Insecurity, but also indignation and anger; other participants (4 and 7 below) provoking indignation and discontent; and the Chinese people, characterised as triggering hatred, disgust and worry (in 5 below).

\subsection{Expression}

The expression of $A F F E C T$ in Macedonian differs from the prototypical adjectival phrase found in English, noted in Martin and White (2005). While there is an equal representation of explicit and implicit evaluation, for explicit values, it is evident that in Macedonian the predominant structure is a verbal phrase, that is, a process, as in: се наяевам 'I hope', креваай йаника 'create panic', also noted in Saračević (2021). Less present are expressions of AFFECT as quality, for instance: нег̄aииива 'negativity', анксиозности 'anxiety', and even less frequent are Epithets and Attributes, as in: иооиресени 'distressed', најӣраг̈ично 'most tragic'.

There are also a number of various pragmatic markers, exclamations, repeated words, capitalised letters, and emojis, such as: аман 'c'mon', лелееее 'OMGGG', : (see example 15 below). They are employed in posts more often to aid the expression of $A F F E C T$, and less often to add an ironic or sarcastic tone to the utterance. Additionally, since the language on the forum closely resembles spoken language, its expression takes the form of or is also aided by idiomatic phrases, such as Госйоя на йомош! 'May God help us!', кај ке им ияе gушайа 'will their soul find rest', as in (14) below.

\section{Discussion}

In this section the realization of the affective categories is discussed in more detail and illustrated with examples (5.1) and the interrelation between affective positioning and the dimensions of INVESTMENT and ALIGNMENT is briefly examined (5.2). 


\subsection{AFFECT categories and patterns of expression}

In what follows, we discuss how AFFECT was expressed in the discussions analysed, and how it needed to be read not only from explicit lexical units, such as 'terrifying' or 'anxiety' but also from discourse level strategies, such as rhetorical questions or repetition. We start with feelings of Insecurity since they were present in a third of the posts analysed. The following examples illustrate more typical expressions of feelings categorised under Insecurity: (1) implies suspicion about the virus origin, since it was most deadly for the elderly, (2) illustrates concern and anxiety triggered by pessimistic local prognoses regarding the virus spread, and (3) exemplifies explicit worry and fear coming from personal experience.

(1) Се сеќкват̄е ӣреg извесно време ког̄а иела евройа зборуваше за неооржливите иеензиски фоноови? Мислам дека и во Макеgонија имаше иериоо ког̄а се зборуваше за йоа, нели е малку чуяно шйо овој вирус е ойасен најмногуу за лииа ная 60 гооина? Само ушйе еона йеорија на заг̄овор. ${ }^{2}$ (supporter)

'Don't you remember that some time ago through the whole of Europe there were talks about the pension funds? I think that in Macedonia there were such talks at some point, isn't it a little bit suspicious that this virus is risky mostly for people older than 60? Just one more conspiracy theory.'

(2) Имало на йв яоктиор оя мк и објавил [...] яека кај нас можело gа бияай околу 500000 заразени, 250000 хосииитализирани во болници, и околу 2000 мрйви. Луг̃е и тиахикароија и несоница и жешйина, се осеќам йосле ова. Анксиозносйа ме найауна вечерва. (supporter) 'There was [allegedly] a doctor from Macedonia on TV who reported [...] that in our country there could be about 500,000 infected, 250,000 hospitalised, and about 2,000 dead. People, I got tachycardia, I got insomnia, I got heatwaves, I feel it all after this. Anxiety hit me tonight.'

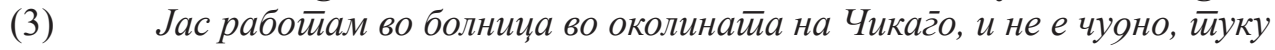
е аларманйно и засиирашувачко. (uncertain)

'I work in a hospital in the vicinity of Chicago, and it is not strange, it is alarming and terrifying.'

It is expected that the expression of suspicion in (1) is to be read not only from 'a little bit strange' but also from the rhetorical questions raised, the question tag 'isn't it', and the rather bold statement in the last sentence. In (2) there are multiple words to convey concern, including anxiety itself, but the repetition also contributes to a more intense feeling of Insecurity. Example (3) contains strong negative lexical items to convey worry and fear.

Another third of posts reveals feelings of Unhappiness, which often accompany feelings of Insecurity. Example (4) below illustrates indignation towards internal subjects, in this case a supporter, while (5) and (6) illustrate contempt and hatred

\footnotetext{
${ }^{2}$ Example posts are provided here in their original form, as written on the fora. The translation is the authors'. Bolding is added for emphasis of expressions relevant to the discussion.
} 
towards external subjects: in (5) towards the Chinese and in (6) towards a WHO representative.

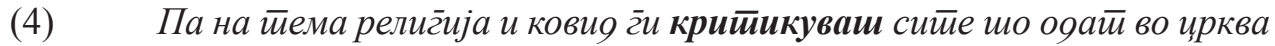
во ваква йаноемија, а овое шириш ӣройаг̄аноа оека вирусов усиивари

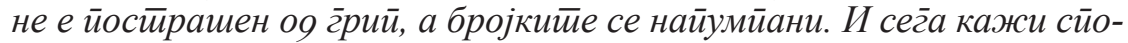
рео йебе йаноемијава е реална закана или не е? Или е ойасна само

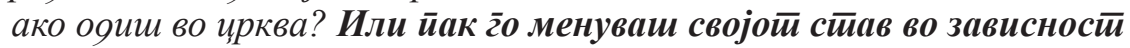
оо сийуацијайа? (opponent)

'Well, on the topic of religion and Covid you criticize everyone who goes to church during this pandemic, and here you spread propaganda that the virus is in fact not worse than the flu, and that the death toll is exaggerated. And now you tell me, is the pandemic a real threat or not? Or is it dangerous only if you go to the church? Or you change your position based on the situation?'

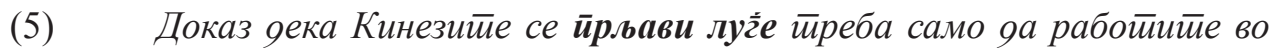
хойел. Тоа се најужаснийе луг̈е на йланейава а башка и смроай. Јаяеле суйа оя лилјак и ойровна змија и йака се заразиле. Нормално, ког̄а во йамейой се забег̄ани. (opponent)

'A proof that the Chinese are dirty people, this you can get by just working in a hotel. They are the most disgusting people on this planet, and they stink. They [allegedly] were eating a bat and poisonous snake soup and got infected. Of course, when they are nuts.

(6) [...] Инаку вчера баш ми йаяна у око, еона г̄нияа срйска ӣрестиавник на Сзо кажа оека во сейиември вйор бран се очекувал и йоа йо-

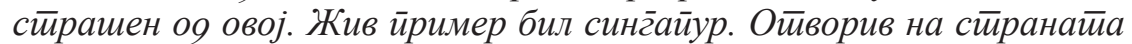
coronalive баш gа виоам шито било во Синг̄айур. Буквално никаков вйор бран,никаков вӣор ӣик, абе све најмило оа му ебам! Мајка


скроз. (supporter)

'[...] BTW, I just noticed yesterday one Serbian scumbag, a representative of WHO, said that they [allegedly] expect a second wave in September, a worse one. He gave Singapore as an example. I opened the coronalive webpage to see what's going on in Singapore. Literally no second wave, no second peak, the fuck with him! The panic media are causing fucked us all up. They drove people nuts.'

The expression of indignation towards other participants in the discussion was most frequently used by opponents to negatively evaluate and criticize supporters of CTs, either in a direct confrontation as in (4) or indirectly through expressing indignation or dislike towards third parties which supporters endorse. In (4) indignation is evoked through a series of questions accusing the interlocutor of being contradictory and hypocritical. In (5) there is explicit hate speech towards the Chinese, seen as the culprits, which is encountered in posts from all groups. Expletives, as the curses in (6), appear in a number of posts, especially in those expressing Unhappiness and Dissatisfaction towards external subjects, usually officials and 
media. Such expressions do not only convey negative feelings but also help intensify them and usually stretch over a longer post.

Dissatisfaction as the third most present group of negative feelings (found in about a fifth of posts) was expressed mainly as discontent, anger, frustration and disappointment, illustrated in examples (7) and (8). The former conveys a mild implicit discontent by participants' behaviour, in the form of a request, and the latter a stronger combination of anger and frustration triggered by official reports and measures, which is also present in (6) above. In (9) there is disappointment which gradually turns into suspicion, concern and pessimism. Such combinations of feelings from different categories are discussed below.

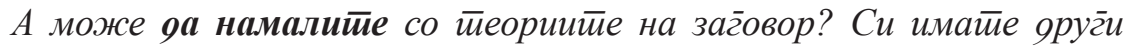
иемлизатиоа. @Moderator (opponent)

'Can you slow down with these conspiracy theories? You have other threads for that.@Moderator'

Добро овие СЗО, свесно яека никој веке не гіи ебе 2 йосйо сеушйе иравай конференции секој оен? Глеам денеска еуна луоа кучка објаснуе яека ќе имало вйор бран иомито населениетио немало имунийети. Па ообро како ќе има коа йо фома не зайворивйе као леирозни!? (supporter)

'Okay, these people from WHO, aware that no one gives a fuck about them anymore, still hold conferences every day? I watched one crazy bitch today explaining that there will be a second wave because people had no immunity. Well how can they have when you locked us up as if we were lepers!?'

In one-third of the posts, there was a combination of multiple feelings belonging to two, three or more of the categories of AFFECT. The most commonly present combinations were the following: 1) Unhappiness + Insecurity, 2) Unhappiness + Dissatisfaction, 3) Dissatisfaction + Insecurity, and 4) Unhappiness + Insecurity + Dissatisfaction. These are illustrated in some of the examples above, but also in (9) and (10) below.

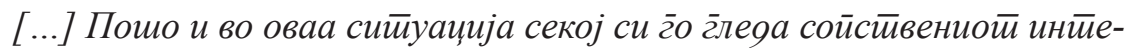
рес. [...] Ни вонреяна сосйојба, ни кризна. Ни сайлам фунционира йоа со забранитете за влез. Заборавиле яа објавай во служсен, йа Аерояромой и яенес функционира. Тие йолицајцฺиие во Дебар за 1000че


во Сйруг̃a, а не во Охрия и се крие ииој иоояайок. И ушйе којзнае ийо се крие... Само Госйоя оа ни е найомош. (supporter)

'[...] Since in this situation everyone's working for their own benefit, [...] Neither emergency situation, nor crisis. Nor the entrance ban functions properly. They forgot to issue it in the Official Gazette, so the Airport's still working today. Those police officers in Debar would let citizens exit the city for a 1000 denars. The woman in labour from Labunista, is hos- 
pitalised in Struga, not in Ohrid, and they are hiding this information. And who knows what else they are hiding... May God help us.'

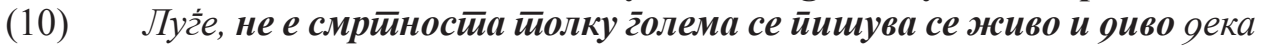
е оя корона ког̄а ќе йочине раои йари. Ова не е лаички муабети и не

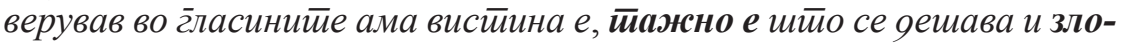
уйойреба на ситиуачијайа раои нечии йрофийи :/(supporter) 'People, the death toll isn't that high, just saying left and right that people are dying from the Corona for money. This isn't just lay talk and I didn't believe the rumours, but it is true, and it's sad that abuse of the situation is going on for someone's profit :/'

In (9) there is disappointment by the local situation, expressed through repeated negation (failure to deal with the situation) and reported speech statements, suspicion raised by a rhetorical statement, pessimism, and misery conveyed by an idiomatic phrase 'May God help us'. (10) on the other hand starts with raising suspicion and distrust in local authorities and media by negating their claims and providing an alternative explanation, followed by explicit expression of sadness and aided by the negative concept of 'abuse' to convey concern and frustration.

\subsection{AFFECT in relation to investment and alignment}

Positioning oneself on the affective scale is only one aspect of stancetaking. It is multiply interrelated with the other two dimensions (investment and alignment), which together create a stance "as a single unified act" (Du Bois 2007: 162). Du Bois's (2007) view of stance as a set of triangular relations has been most influential in the sociolinguistically oriented studies of stance. Following this concept, Kiesling et al. (2018: 708) "consider stancetaking as a multidimensional construct indicating the relationship between the audience, topic, and talk itself".

Since the three dimensions of stance arise at the same time in a single speech activity they are inevitably interwoven and together contribute to the overall stance effect. Du Bois and Kärkkäinen (2012: 446) put it this way: "We present a view of stance as a triplex act, achieved through overt communicative means, in which participants evaluate something, and thereby position themselves, and thereby align with co-participants in interaction." Looking at AFFECT we present only one aspect of stance, but it can reveal more than just the evaluative character of the discussion sequences examined. AFFECT can shape and/or modify commitment and is employed in establishing alignment with the interlocutors. By expressing emotions towards an entity that is the focus of the talk one simultaneously communicates the level of investment in the view expressed and creates some kind of relation with the addressee(s). ${ }^{3}$

Indeed, a closer look at the forum posts makes it clear that the linguistic and discourse means are employed for multiple functions that create the general stance. A typical example are the statements implying higher confidence or conviction of the speaker, which are usually marked by intensifying adverbs or adjectives, predicates expressing certainty, adversative markers, negation, repetition, rhetorical questions,

\footnotetext{
${ }^{3}$ Du Bois and Kärkkäinen (2012: 440 and 446) express a similar view.
} 
intensifying particles, exclamations, strong lexical items and/or paraverbal means (Mitkovska and Saračević 2021). However, these strengthening strategies go hand in hand with strong, usually negative, feelings in these posts and usually signal disalignment with the interlocutor(s), such as disagreement, challenge, confrontation. ${ }^{4}$ In example (11), the direct sarcastic address to all reveals the discussant's opposition to a previous comment that the media reports are confusing and produce tension and should be avoided, but it also indicates feelings of indignation and dissatisfaction which are then elaborated and extended to external entities (domestic information agencies).

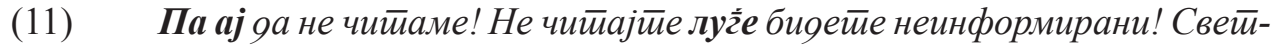
ски меоиуми информираай яека Американците зайочнаа биолошка


яецении наназая со образование со кулииура со се. (supporter)

'Then let's not read! Don't read people be uninformed! World media inform that the Americans are beginning a biological war with China but ours don't broadcast anything and that is why we are decades behind with education with culture with everything.'

In (12) the starting exclamation and the prompting particle 'aj', paired with derogatory lexis (fake nеws, гллуйосйu 'nonsense'), intensify the writer's attitude that reading and believing all that is on social media is wrong. At the same time, the post communicates strong feelings of anger and contempt directed towards the addressee, as well as escalation of disagreement which aggravates the relations. Actually, the challenge is taken as a strong criticism and the ensuing response is a fierce attack at the author and all those sharing their views.

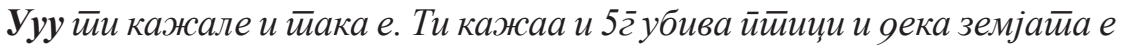
рамна? Ај иои чийај йа fake news и йишувај йа гллуйосий. (opponent) 'Wow you've been told and that's it. You've also been told that $5 \mathrm{~g}$ kills the birds and that the earth is flat? Go and read fake news and write nonsense again.'

In relation to this, we can also point out questions, and especially rhetorical questions, which are often used to strengthen the position. Opponents use them typically to counter or challenge some claim, evoking indignation or contempt to opposing interlocutors, as in (12), where the writer assumes domination by implying superior knowledge. In supporters' posts rhetorical questions pose as obvious conclusions, conveying suspicion, often coupled with anger or dissatisfaction. The question in (13), stated indirectly, functions as a proof for suspicion rather than a request for an answer.

Добро бе кажи ми йи яали истиойо не гоо йравеа во иериояой оя 2008 gо 2010 гоомина. (supporter)

\footnotetext{
${ }^{4}$ Compare Biber and Finegan (1989: 111) for a similar comment. See also Du Bois and Kärkkäinen
} (2012: 446). 
Well then you tell me didn't they do the same during the period from 2008 to 2010 .'

Weakening strategies, such as hedges and distancing phrases, lower the directness of the statement and thus attenuate face-threatening acts such as disagreement or challenge, for face-saving purposes or to avoid conflict. Often, however, the author of the post does not intend to lower the intensity of investment into the claim and diminish the commitment to the expressed view. The strength of the claim is often achieved by increasing the $A F F E C T$ intensity. This is illustrated with the statements presented in Table 4, which are extracts from a longer sequence on the topic: rumours that the families of the dead are offered money to register them as Corona diseased, even though they may not at all have been infected. Contributor A elaborates on a question posed in a previous post, by expressing a strong suspicion that the rumours are true. Despite the uncertainty hinted by the verb изглеga 'it seems', the adverb навистинна 'really' and the collocation яебело зарабойува 'get filthy rich' intensify the feeling that there is something terrible going on and reinforce the concern.

Contributor B responds to this suspicion with a disagreement, which is softened by a preceding comment that sounds like a partial agreement, the distancing phrase не знам 'I don't know' and the use of the dative to avoid responsibility for the claim. It does not, however, sound at all uncertain, due to the use of the long pronoun (мене), which has an emphatic effect, and the superlative ирремногу 'too much'.

Table 4. Sequence example

\section{Content}

Во кониекести на муабет̄ов за вирусов и измислицийе qа речам, луѓе, нависииина нас обич-

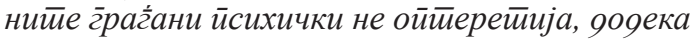

A некој фебело изг̃леgа зарабойува. [...] (supp)

'In context of this talks about the virus and the so called fabrications, people, we ordinary citizens are really psychologically burdened, while someone seems to be getting filthy rich.

XX Grouper еве си г̄о ӣрошири бизнисой ако не өруг̄о, ама не знам, мене ова со јавувањайа ми В е иремногуу за яа е вистиина. (орр)

Re: A 'XX Grouper has expanded its business if nothing else, but I do not know, this with the calls is too much for me to be true.'

\section{AfFect Alignment}

$\begin{array}{ll}\text { suspicion, } & \begin{array}{l}\text { neutral } \\ \text { concern }\end{array} \\ & \text { elignment: } \\ & \text { elaboration }\end{array}$

disalignment with opposing: disagreement

We can see in this short sequence how AFFECT is correlated with the other two dimensions so that the author's views are not compromised despite the weakening at other levels for pragmatic purposes. The topics discussed in the analysed threads are provoking and the participants adhere to divergent views, thus there is imminent 
danger of conflicting exchanges. Nevertheless, most of the interaction is carried out in unmarked, non-polite ${ }^{5}$ manner, as the contributors adjust their expression so as not to threaten their and other participants' face. As pointed out above, conflicts do arise if the manner of expression is kept at high intensity at all levels and especially if the argument is shifted to personal level (see example 12).

\section{Conclusions}

In this study we presented a discourse-semantic analysis of affective positioning in Macedonian internet forum discussions on the topic of COVID-19 related conspiracy theories. The analysis was conducted on a sample of sequences of posts contributed to two threads, with focus on semantics, polarity, orientation and expression of $A F F E C T$, as well as the role of $A F F E C T$ in general stancetaking. The findings reveal that the topic of discussion being a precarious situation largely contributed to the polarity of feelings expressed to be mostly negative, pertaining to Insecurity, Unhappiness and Dissatisfaction. Other internal factors, such as the other participants and what they shared, and additional external factors, such as the media, the health officials and some groups of people, were also found to be the trigger for this negativity. The most common way participants expressed explicit affective evaluation proved to be a verbal phrase. Implicit evaluations appeared as often as explicit ones, with feelings occupying a whole post, often graduated or combined with explicit values, and additionally coupled with discourse-level strategies to express stance. While affective evaluation was found to serve participants to express their emotional states and reactions, it nonetheless aided participants' taking stance and strengthening or weakening their and others' claims for various interactional purposes.

\section{References}

Angouri, J. and Tseliga, T. (2010). "You Have No Idea What You are Talking About!" From e-disagreement to e-impoliteness in two online fora. Journal of Politeness Research $6(1), 57-82$.

Arendholz, J. (2013). (In)Appropriate online behaviour: a pragmatic analysis of message board relations. Amsterdam/Philadelphia: John Benjamins Publishing.

Barton, D. and Lee, C. (2013). Language online. London: Routledge.

Biber, D. and Finegan, E. (1989). Styles of stance in English: Lexical and grammatical marking of evidentiality and affect. Text 9 (1), 93-124.

Bou-Franch, P. and Garcès-Conejos Blitvich, P. (2018). Analyzing Digital Discourse: New Insights and Future Directions (1st. ed.). Palgrave Macmillan.

Du Bois, J. W. (2007). The stance triangle. In R. Englebretson (ed.). Stance taking in Discourse: Subjectivity, Evaluation, Interaction, 139-182. Amsterdam: John Benjamins.

\footnotetext{
${ }^{5}$ Locher (2006: 255-256) suggests four levels of politeness which represent a continuum: (a) impolite + inappropriate/non-politic + negatively marked; (b) non-polite + appropriate/politic + unmarked; (c) polite + appropriate/politic + positively marked; and (d) over-polite + inappropriate/non-politic + negatively marked.
} 
Du Bois, J. W. and Kärkkäinen, E. (2012). Taking a stance on emotion: affect, sequence, and intersubjectivity in dialogic interaction. Text \& Talk 32-4: 433-451. DOI 10.1515/ text-2012-0021.

Ehrhardt, C. (2014). Politeness and face work in German forum communication. In K. Bedijs, G. Held, \& C. Maaß (eds.). Face Work and Social Media, 84-107. Münster: Lit-Verlag.

Halliday, M. A. K. (1978). Language as Social Semiotic, the social interpretation of language and meaning. London: Edward Arnold.

Herring, S. C. (1992). Gender and participation in computer-mediated linguistic discourse. Washington, D.C.: ERIC Clearinghouse on Languages and Linguistics, document ED345552. http://ella.slis.indiana.edu/ herring/participation.1992.pdf

Herring, S. C. (2002). Computer-mediated communication on the Internet. Annual Review of Information Science and Technology 36, 109-168. http://ella.slis.indiana.edu/ herring/arist.2002.pdf

Kiesling, S. F., Pavalanathan, U., Fitzpatrick, J., Han, X. and Eisenstein, J. (2018). Interactional Stancetaking in Online Fora. Computational Linguistics, Volume 44, Issue 4: 683-718.

Locher, M. A. (2006). Polite behavior within relational work: the discursive approach to politeness. Multilingua 25 (3), 249-267.

Martin, J. R. (2000). Beyond Exchange: Appraisal Systems in English. Evaluation in Text, $142-175$.

Martin, J. R. and White, P.R.R. (2005). The Language of Evaluation: Appraisal in English. London \& New York: Palgrave/Macmillan.

Saračević, F. (2021). Interpersonal discourse-semantic analysis: appraisal in an online discussion forum [Unpublished master's thesis]. AUE-FON University, Skopje. DOI: 10.13140/RG.2.2.18401.22882

Shum, W. and Lee, C. (2013). (Im)politeness and disagreement in two Hong Kong Internet discussion forums. Journal of Pragmatics 50, 52-83.

Митковска, Л. и Сарачевиќ, Ф. (2021). Дискурсната динамика на една форумска дискусија. Во Кусевска, М. и Ивановска, Б. Праг̄майички исииражувања. Штип: Универзитет Гоце Делчев. [Mitkovska, L. and Saračević, F. (2021). Discourse Dynamics of one forum discussion. In Kusevska, M., \& Ivanovska, B. Pragmatic Studies. Stip: University Goce Delcev.] 
